Research Report No. 32/2008

\title{
Revisiting the Democratic Deficit: The Urgent Case for Political Party Think Tanks
}

Irvin Studin

Follow this and additional works at: http://digitalcommons.osgoode.yorku.ca/clpe

\section{Recommended Citation}

Studin, Irvin, "Revisiting the Democratic Deficit: The Urgent Case for Political Party Think Tanks" (2008). Comparative Research in Law of Political Economy. Research Paper No. 32/2008.

http://digitalcommons.osgoode.yorku.ca/clpe/203 


\section{Comparative Research in Law \& Political Economy}

Irvin Studin

Revisiting the Democratic Deficit: The Urgent Case for Political Party Think Tanks

EDrTORS: Peer Zumbansen (Osgoode Hall Law School, Toronto, Director, Comparative Research in Law and Political Economy, York University), J ohn W. Cioffi (University of California at Riverside), Lindsay Krauss (Osgoode Hall Law School, Toronto, Production Editor) 

CLPE Research Paper 32/2008

Vol. 04 No. 07 (2008)

\title{
Irvin Studin
}

\section{ReVisiting THE Democratic Deficit: The URgent CASE FOR POLITICAL PARTy ThinK TANKS}

\begin{abstract}
In this article, Irvin Studin, of Osgoode Hall Law School and formerly of the Privy Council Office, argues that Canada's true democratic deficit lies in the incumbency and division of labour advantages of an increasingly complex federal bureaucracy over an 'unarmed' elected executive. He proposes that state-funded political party think tanks be created to remedy the problem.
\end{abstract}

Keywords: democratic deficit, Canada, think tank, federal politics, Cabinet, executive branch of government

JEL classification: H11, H83

\section{Author Contact:}

Irvin Studin

Osgoode Hall Law School, York University

4700 Keele St, Toronto Ontario, M3J 1P3

Email: istudin@hotmail.com 


\title{
REVISITING THE DEMOCRATIC DEFICIT: THE URgent CASE For POLITICAL PARTy Think TANKS
}

\author{
Irvin Studin ${ }^{*}$
}

\begin{abstract}
During the course of his long years in power, Bismarck brought his ministerial colleagues into unconditional bureaucratic dependence by eliminating all independent statesmen. Upon his retirement, he saw to his surprise that they continued to manage their offices unconcerned and undismayed, as if he had not been the master mind and creator of these creatures, but rather as if some single figure had been exchanged for some other figure in the bureaucratic machine.
\end{abstract}

Max Weber, Wirthschaft und Gesellschaft (1922)

Barring a major new war, the year 2007-2008 may well be remembered in history as one of political transitions - changes in government-for the West's major democracies. Before Kevin Rudd, the newly elected prime minister of Australia, there was Gordon Brown in the United Kingdom, and also Nicolas Sarkozy in France. By the end of calendar 2008, we will have a newly elected president of the United States and, in all likelihood, a general election in our own Canada. (New Zealand, for the record, will also have a general election by mid-November of 2008. Gordon Brown may also call a general election.)

\footnotetext{
* Irvin Studin, a Rhodes Scholar, was the first-ever recruit of the Privy Council Office targeted recruitment campaign-now known as the Recruitment of Policy Leaders programme-in 2002. He worked at the Privy Council Office as a foreign and security policy specialist between 2002 and 2006, and as a secondee in the Department of the Prime Minister and Cabinet of the Australian Government in Canberra between 2005 and 2006. Studin is the editor of What is a Canadian: Forty-Three Thought-Provoking Responses (Douglas Gibson Books, McClelland \& Stewart, 2006). He is currently based at Osgoode Hall Law School at Toronto's York University, where he lectures.
} 
Transitions of government-peaceful transitions of governmentafter free and fair elections are the very lifeblood of modern democratic life. That much is reasonably clear. A government is elected on the strength of undertakings made to the voting public, which in turn is supposed to hold the government to account for such undertakings and for its general competence. The logic appears tight-assailable not on principles, although perhaps in the details... Is it?

Conceding the battle on principles, let us look at details—for much of Canada's governance happens in the bowels, well beneath the rambunctious veneer of parliamentary repartee and media bons mots... This article will seek to make the case for a more powerful or empowered political executive in Canada — at least at the federal level. It will argue that our political parties are in dire need of designated policy think tankspreferably state-funded tanks - in order that they be able to form stronger, deeper and, most importantly, more consistently prepared governments when they come to power. The case being made, therefore, is that a more effective political executive is the critical lynchpin in strengthening modern Canadian democracy.

All this clearly goes against the grain of the conventional or accepted wisdom of recent political debates in Canada about the soi-disant 'democratic deficit,' and is contrary to the general thrust of public and academic critiques of Canadian government going back to at least the 1970s-most of which have, in one form or another, stressed the democratic virtue of defanging an increasing large and potent executive. Part of this proposed defanging often involves bolstering the role of legislative branch, or Parliament: the effectiveness of its committees, the voting freedom of members and, more recently, the system by which members are elected and hence its composition and representativeness.

The 'democratic deficit' of the last decade or so has traditionally been attributed to the "friendly dictatorship" of the executive branch of the federal government. The typical ill associated with Canadian government and governance at large on this view of the world has been the apparent excess of political and administrative power vested in the prime minister and his supporting machinery - to wit, the Prime Minister's Office (PMO) and the Privy Council Office (PCO), both of which are apparently all too disposed to usurping power from other branches of government- 
especially Parliament-but also from other parts of the executive- -that is, from other ministries, and even from full Cabinet. The apparent usurpation of power from Parliament, of course, has garnered the most political and media attention, and suggests a weakening of the democratic structure of our Westminister system of (responsible) government-one in which an effective Parliament is able to meaningfully hold the executive to account.

This discourse of an 'emasculated' or 'irrelevant' Parliament has a long history. Indeed, as early as 1969, then Prime Minister Pierre Trudeau said that "[w]hen they are fifty yards from Parliament Hill, [Members of Parliament] are no longer honourable members, they are just nobodies." Pearson before him spoke of executive dictatorship in the context of Canadian democracy, but the modern discourse begins specifically with Trudeau, as it was the Trudeau government that introduced the elaborate cabinet committee system which ushered in the modern power era of the three central agencies in Ottawa-Finance, Treasury Board and, in particular, the PCO. Along with its political annex in the form of the PMO, the PCO became primus inter pares in the art of "governing from the centre"-principally on the strength of its control of the cabinet committee process, including full Cabinet. To the Clerk of the Privy Council-head of the PCO and also chief bureaucratic advisor to the Prime Minister (leaving aside his role as head of the entire public service) - eventually accrued more administrative power than that of most Cabinet ministers, and the degree of dependence on the Clerk by more powerful men and women like the Prime Minister and the chief of staff to the Prime Minister became an undeniable, but (critically) little understood, fact of Canadian political life.

Because governments since Trudeau have both developed and advanced their broad policy agendae primarily through the modern cabinet committee process, mid- to high-level officials in the PCO have also become extremely powerful players in government, influencing not only the substance of policy discussions, but providing final recommendations-given effective delegated authority from the Clerk, and via the implied imprimatur of the Prime Minister- to chairs of cabinet committees on what policies and directions should be approved (or not) and, less widely appreciated, accelerating or decelerating the pace at which a given file or issue weaves its way through the increasingly 
complex cabinet committee system, depending on the interplay of political and bureaucratic imperatives and intrigue. Under any given government, there may be between half a dozen and a dozen such committees-both standing and ad hoc. They cover the entire gamut of policy issues faced by the country (at least from the federal perspective), from national security and foreign affairs to economic, social and environmental questions, and even national unity. And each of these committees is supported by at least one secretariat (and sometimes more than one) within the PCO, which is populated by a not insignificant number of policy professionals - civil servants with strong experience of government and often with specific policy expertise. These civil servants usually take the lead in setting the lion's share of the agendae for cabinet committee meetings and, in many cases, meetings of full cabinet. They also manage virtually all of the paperwork leading up to, and issuing from, these meetings. This monopoly or mastery of the process of government by elite civil servants is, again, little understood, but absolutely essential to a proper appreciation of how modern government in Canada really works.

For the most part, full cabinet in this system tends to receive policy advice or recommendations for consideration for which most of the details have already been plied by officials in PCO (primarily) and the other central agencies (secondarily), with support from other specialized ministries (so-called 'line departments'), each of which, significantly, can call on the expertise and incumbency of a large number of policy professionals in their own ranks. The policy marge de manoeuvre for cabinet ministers and their political officials in this structure of decisionmaking is thus quite limited. They provide general 'thematic' or 'value' direction, intervene substantively (although often superficially) on major priority files, and do their best to 'put out fires,' where these can be predicted, on highly sensitive files. Where battles are fought over particular files, ministers must be selective, as the number of files passing through the committee system is very large, and does not permit of considerable recycling of processes and debates. (Most files will only come to a given committee once-and for expected approval only.) Some ministers and political officials, including in the PMO, if deft and not distracted, will anticipate disagreements on particular issues prior to committee meetings, and will work out problems 'on the side.' But again, a significant majority of the details of policy are proposed, discussed and 'ironed out' at the bureaucratic level, mediated by the centre, and iterated 
through interdepartmental meetings, committees and consultations at levels that are well below the levels not only of the senior bureaucracy, but of cabinet ministers, their political officials and the PMO. The Clerk, through his officials in the PCO, is, for all practical intents and purposes, the master of this process of policy development and approval.

In addition to control of the cabinet committee process, the PCO, supported by the entire government policy bureaucracy, plays a massive role in developing the effective government agenda by, first and foremost, providing what is called 'transition advice' to an incoming prime minister: thick policy books on everything from machinery of government through to economic policy, social policy and foreign and security policy. These policy books, although not usually 'cutting edge' or 'revolutionary,' typically provide a comprehensive brief on the state of the country (or the federal ministries) and strong advice on the preparation of a policy agenda for a new government. While the Clerk, aided by PCO officials, usually dominates this process, the said advice, critically, usually incorporates the input of most ministries of government, particularly at senior (deputy or assistant deputy minister) levels, supported in turn by the input of large complements of lower policy analysts in the various ministries. This transition advice often provides detailed commentary on the electoral platform (promises) and the anticipated priorities of an incoming prime minister. Such advice will often take a position - a yea, nay or maybeon the 'doability' or 'wisdom' or 'reasonableness' of a certain initiative or policy proposed during an election. It may also-and this is certainly not unheard of-take positions on issues or files independently of, or notwithstanding, the electoral promises made by the party in power: that is, it may propose a policy agenda that, while politically sensitive, is reflective of the very best advice of the bureaucracy. In the aggregate, this final package or product is intended to both impress the incoming prime minister in respect of the competence of his or her civil service (and the PCO, his ministry, in particular) and to impress upon the prime minister that the civil service's advice (its position) is supported by serious policy professionals - technocrats, if you will-from across government: in other words, that it is 'good' advice, that it is legitimate. And that he or she would be wise to strongly consider it.

So a lot, as mentioned, happens below the surface and radar of the political (elected) level—and clearly well before ever reaching Parliament 
and the public. This is, of course, as it must be, for the most part, in our Westminster system: a professional, largely anonymous, discreet and politically neutral civil service speaks 'truth to power,' with the key executive processes of government decision-making headquartered in the PCO (or cabinet office), and with much of the advice either being provided directly by the PCO or through the PCO after consultation or brokering with more specialist line departments. The essential point, however, for our purposes, is that the advice proffered by the civil service is more often than not supported not only by a very large number-dare I say, an army - of policy professionals (technocrats) with longstanding experience (incumbency) in specific areas of policy (e.g. foreign affairs, national security or tax policy), but also a bureaucratic apparatus which profits from a very fine division of labour both within individual ministries and across the entire leviathan of government. And here we get to the heart of the matter: This prolific division of labour allows the civil service, in preparing advice for the government-whether in the context of transition or that of day-to-day government-to analyze any given policy issue or problem from a myriad of perspectives-typically with each section or division of a (relevant) ministry providing analysis from its perspective and, in turn, each (relevant) ministry providing aggregated analysis from the ministry's perspective, with PCO contradicting, challenging, coordinating or collating these different perspectives to provide a so-called 'whole-of-government' view on a given matter. (As a general rule, 'whole-of-ministry' advice on specific files, similarly, is given on a regular basis to cabinet ministers and their political officials in their given ministries. Such advice only passes through PCO only if, and to the extent that, it touches on the overall government agenda or involves peculiar political sensitivities.)

A gross truism at this point in today's globalization discourse is that as our country and our world become ever complex, the scale of bureaucracy needed to tackle given issues grows-often exponentially. Witness the massive increase in national security and defence bureaucracies in the West in the aftermath of the September 11, $2001 \mathrm{Al}$ Qaeda attacks on the United States. These modern bureaucracies in both the private and public sectors are indispensable to modern societies in virtue of the very fact that they are 'stable' (that is, they have standing capacities and well-rehearsed internal rules and regulations) and are equipped with a prolific division of labour — one that can be increased with 
relative ease - to tackle modern problems. (Said Weber: "The needs of mass administration make it today completely indispensable. The choice is only between bureaucracy and dilettantism in the field of administration.”) In short, an army of bureaucrats awaits for any given issue-and many of them, having been bureaucrats for sustained periods of time, may become very specialized indeed in a given aspect of a particular issue, or even sub-issue. By their very nature, bureaucracies can call on the services of many such specialists - incumbents, if you will-to tackle most species of problems.

Enter politics and the need for a democratically elected executive (prime minister and cabinet). Conventional renderings of this executive hold that, in the context of the Westminster system and a parliamentary majority, the prime minister and the PMO will jealously control the apparatus of government and — with limited debate and compromise-ram their agenda through or, on occasion, around, a Parliament in which members are largely powerless and parties generally disciplined. So, the argument goes, there must be a democratic deficit. Moves to bolster the muscle and 'legitimacy' of Parliament are mooted. Various arm's length bodies are stood up to oversee and audit government. Public inquiries are launched to investigate abuses of executive power.

Allow me to stir a little, however, and humbly propose that the fundamental problem with this conventional view of politics and public administration in Canada is that it severely understates or completely ignores the centrality - the dominant centrality, if you will—of the standing bureaucracy, with PCO as its hub, in the policy-making process in Ottawa. The power of this bureaucracy, as mentioned, comes from two key facts: incumbency and division of power. Both of these facts are amoral: neither good nor bad in and of themselves; rather, they are true of most serious, modern bureaucracies, and particularly true of the biggest bureaucracy of them all-that of a large, central government. Incumbency means that many bureaucrats, having been in their ministries, their area of policy or in 'the system' (the civil service) for sustained periods of time, know their issues 'cold' and, just as importantly, know the levers and valves - the norms, rules, regulations and processes - of the administrative behemoth called the 'federal government.' They have a strong sense of what can be done and what cannot reasonably be done, given the constraints of the system. And, quite naturally, human nature oblige, they 
are not bereft of biases-some more implicit than others-as to what should be done and what should not be done, irrespective of which party is in power, and even if they may lack a specific public 'mandate' to advance such biases.

On the other hand, an elected government-especially a newly elected government-is typically populated by a prime minister who, by virtue of a certain political experience and professional training, may well have become a policy specialist or 'wonk' in one or more areas (although not necessarily in any), and a cabinet comprised of individuals who are not necessarily specialist in any area of policy-let alone the area of policy occupied by their particular ministries. Policy expertise aside, none of these individuals, including perhaps the prime minister, necessarily has any administrative experience in government. Perhaps just as signally, the political officials supporting the prime minister in the PMO, and those who populate ministers' offices (mostly party loyalists), also often have limited specific policy expertise and limited experience in government. Their understanding of the actual functioning of government is more often than not poor, $a b$ initio, if not altogether naïve. (Needless to say, almost: opposition is a poor training ground for government.)

Seen against the incumbency and division of labour of a bureaucracy that, in the context of our complex society, is ever largeeven leaving aside its inherent tendency to self-reproduce-today's real democratic deficit seems plain: the political executive is weak, thin and unarmed. It is ill-equipped to govern, public appearances of 'competence' notwithstanding. For it soon finds the ship of state exceedingly difficult to steer, and meaningful changes of course in that ship, even if promised and legitimated in the course of a properly fought election, often very difficult to execute. The idea, then, that a party, when coming to power or even when well established in power, can easily give robust 'orders' or 'direction' to the bureaucracy, and that the latter will simply 'administer' or 'implement' now begins to appear quite abstract indeed...

A prime minister and party may come to power with a small set of priorities, typically approved through election, and underpinned by a presumed value system or framework for decision-making on non-priority files. In reality, however, once in government, they quickly discover that it takes a while to figure out how the 'internal' policy decision-making 
system in Ottawa actually works (from policy development processes and meetings to cabinet committees to Cabinet approval), that a good number of its electoral promises - even priorities-are unrealistic or just illadvised (at least according to the civil service brief), and that the civil service-whether openly recalcitrant or not-already has a very large number of issues and files of its own-longstanding files, in many casesthat it is proposing to advance through the new government, usually irrespective of which party is in government. A debate may ensue between political and bureaucratic levels on specific files, or in respect of specific policy recommendations: barring gratuitous use of political authority, the bureaucratic level, by dint of incumbency and division of labour, frequently wins the day on the perceived merit of the argument. The political level-short of policy rebuttals and ill at ease with the process levers of the system - takes the brief. It now takes cues-on both policy and administration-from the bureaucracy. The dynamic of government is set; the Procrustean bed of Canadian policy-making is made. The political executive, in extremis, becomes a talking piece for the bureaucratic machine.

This description evidently oversimplifies matters a little-if only to better illustrate the argument in the article. Granted, the political executive will on occasion give firm and effective instruction on specific matters, and, having considered and analyzed a problem thoroughly, know exactly what it wants, up to the last detail. However, this is more the exception in Canadian government than the general rule. And this rule is that the elected political executive-prime minister, cabinet ministers, and the political officials in their charge - is on most policy and administrative matters well outflanked, outmaneuvered and, over time, ensnared, by a bureaucratic apparatus that has most angles covered. For every rhetorical volley fired by the prime minister or a cabinet minister, and for every 'two-pager' of analysis prepared by a political party in support of an election promise or a proposed policy initiative, the bureaucracy is equipped with dozens, scores or even hundreds of pages of analysisoften iterated and refined over several years. And it can mobilize this analysis to either affirm or contradict the election promise or proposed initiative. If it wishes to contradict or oppose the government on a matter of policy, then it may well 'speak truth to power.' Failing this-and this is not seldom the case-it may exploit its intimate knowledge of the processes of government to frustrate the progress of the file in question. 
(In the case of a minority government or a government in its late stages, the civil service could simply choose to 'game' the government on a particular contentious matter; in other words, to 'wait the government out.') The political executive may well be left wondering why things are moving so slowly, if at all-especially given the civil service's apparent duty to faithfully implement 'government policy.' If, on the other hand, the bureaucracy affirms or supports an initiative, it is then usually tasked by the government with filling in the details-details that the political executive has not thought through (time and capacity constraints oblige), and which are critical to the meaningful delivery of an electoral promise. After all, a two-pager does not a policy make!

But what of legitimacy - specifically democratic legitimacy? The key democratic deficit posited in this article consists in the idea that the political executive in our present political system and culture-one in which the civil service has the overwhelming policy advantage over the government of the day-is ill-equipped to meaningfully deliver on any large-scale, complex policy agenda of its own making. (By complex policy, I do not have in mind mere legislative tinkering or small, sporadic amendments of taxation rates-although these are not bereft of their own 'knock-on' complications. Instead, I refer to major changes or reforms in areas like social policy, foreign policy, environmental policy, etc.) If such a large-scale policy agenda is promised to the electorate in the course of a general election, all the worse: what is the point of a month-long series of national debates and convulsions over a series of policy promises or 'directions' that can nary be delivered in any recognizable form? Does the election not reduce to an exercise in political communications and imagery? The link-the democratic link-between the reasonable expectations of the electorate, based on the articulated policy commitments of the parties aspiring to power, and the actual policy capacity of the parties when in power proves to be tenuous indeed...

So we have our problématique: the democratic deficit lies in the fundamental asymmetry or incongruity or imbalance between the legitimacy of the elected political executive and the overwhelming policycum-administrative power of the modern unelected bureaucracy. This imbalance necessarily grows as the policy environment becomes more complex: files require increasing degrees of expertise, and the incumbency and division of power advantages of the bureaucracy become 
ever significant-unless, of course, the political executive itself becomes far more sophisticated. Rectification of this democratic deficit, it follows, must lie in a redressing of this imbalance: as suggested at the very start of the article, measures must be taken to arm the political executive-more precisely, the parties that may each one day make up the political executive-with the tools that will allow it to more effectively create and advance deep and rigorous policy.

This article argues for the standing up of one serious, dedicated policy think tank for each political party—or at least one for each of the four or five major political parties at the federal level. (Let us simply call these the "Liberal Policy Institute," the "Conservative Policy Institute," etc., or something of similar ilk.) Far more meaningfully than the current regime of political party 'research,' these permanent thinks tanks, housed in proper quarters, would seek to provide each party with deep, standing policy capacity-capacity that could be mobilized or tapped on an ongoing basis or at any time by the leader of the party, whether in government or in opposition. If in government, these think tanks would provide the political executive with a muscular foil to the civil service brief, and would be capable of developing substantive, highly detailed and 'doable' policy plans - plans that would form the basis of the government's instructions to the bureaucracy. These plans could go so far as to provide the government with draft memoranda to cabinet (MCs) and draft lines for legislation, as well as detailed implementation schemes. In the event, the bureaucracy would still play its rightful role of speaking truth to power and providing due diligence, but it would on most files of import be reckoning (or arguing) with a far better prepared political executive: one which has thought through most of the fine points of the different elements of its policy agenda (acts of God aside, naturally), and which is highly deliberate in steering this agenda through the labyrinthine decision-making structures of the bureaucracy.

Power and - second-best - the anticipation of power make the think tanks and their work most relevant. Depending on the file or problem, the government lets its people in the party think tank know what it needs and what the state of affairs (the reality) is inside government. The think tank, in turn, can produce-again, if the party leader wants it to produce. Out of power, the think tank could be used by parties to prepare in significant, practical detail the elements of a potential agenda for 
governing. Far better than the usual ad hoc task forces and country-wide 'round tables' that political parties typically employ on shoe-string budget to develop ideas for future platforms, a serious political think tank would provide the party with its own little standing (professional) army of specialists in various policy areas who could consult, brainstorm, develop and iterate ideas and plans over the course of a sustained period of time, in preparation, hopefully, for power. And indeed, it is the expectation of power that would ideally bring discipline and realism to these ideas and plans.

Who would populate the party think tanks? Critically, they would be populated mostly by thinkers with significant practical experience of government. In other words, the majority of the analysts and planners in the tanks would be former middle- to upper-level civil servants and erstwhile political officials with considerable understanding of the mechanics of government and, ideally, real expertise in one or more areas of public policy. All of them would have to be individuals who have given substantial thought to potential policy reforms in the federal system, and who have proposals in respect of how such reforms, based on their experience in government, could be brought about (executed) in the context of political power - again, up to and including draft memoranda to cabinet, legal opinions in respect of potential Charter challenges and implementation plans that are sophisticated in respect of interdepartmental bureaucratic politics (not just Parliamentary dynamics). Academics or theoreticians with no experience of government and former bureaucrats with little inclination to creative thinking would clearly not be well suited to occupy a large number of spots in such tanks, as the tanks would specifically serve the purpose of providing practical and realistic advice to their party leader for immediate or eventual implementation in government.

The experience-cum-expertise of those in the political think tanks would serve to challenge the incumbency advantage of the civil service. And to challenge the huge division of labour advantage of the civil service, the think tanks would be substantial, impressive operations: not small or boutique operations in the current idiom of independent Canadian think tanks and political party research shops, but significant organizations, consisting perhaps of a hundred or more genuine policy 
people per party think tank, with credible coverage of all of the major policy areas. The picture now gets serious...

It may strike one as controversial, but strong consideration should be given to making these party think tanks state-funded. The genesis of, and policy rationale for, this funding would be an enlightened realization by the government of the day (whatever its stripe) that our democracy is, over the long-run, ill-served by political parties that have negligible indigenous policy capacity. Consistent state funding would therefore provide the backbone for a stable, standing policy capacity for each party. (Philanthropy in Canada is indeed growing rapidly, but under the current party and campaign financing regime, it is difficult to conceive of parties consistently raising an appropriate scale of funds to create stable think tanks-ahead of competing political priorities, no less.) An outside ombudsman position could be created to ensure that parties are properly spending money on research and policy development, and not according to the current political party inclination to allow public relations and electioneering initiatives to cannibalize proper policy planning. An ombudsman could also relieve the state (the government) of the difficult impression that it is somehow 'prescribing' or 'dictating' appropriate behaviour for the political parties — even if it effectively does so in myriad areas already.

Far from usurping the role of the civil service, proper, state-funded political party think tanks in Canada would provide each of the political parties that really compete for political power in our country to be properly equipped with a standing policy bureaucracy that is its very own, and which systematically prepares plans and advice for it alone. This innovation would doubtless enable the political party to propose more robust policy initiatives when in opposition (if it so wishes) or in the course of an election campaign (again, if it so wishes, and if election strategy permits). Even in the absence of actual articulation of such substantive policy initiatives in an actual election campaign, a think tank capacity would afford the party the opportunity (again, if the party wishes to profit from it) to properly table and execute its 'real' plans when in power. In the event, it could well be envisaged that many of those in the think tank who would have prepared the policy plans would, when the party forms government, come to populate some, if not most, of the PMO and the ministers' offices. A government could then presumably hit its 
stride far more rapidly, and with greater punch; transitions of power would be smoother; and the civil service, while still playing its traditional advisory-administrative role, would get its 'marching orders' from political 'masters' who, by and large, know what they want, know of what they speak, and know with whom they are dealing - to wit, an increasingly complex and sophisticated regulatory bureaucracy.

The real democratic deficit would be eased, if not solved. To be sure, the party think tanks would be no panacea, nor would they be at all relevant in the case of a charlatan leader who ascends to power and yet wants nothing of real policy and reform. The critical point, however, is that the think tanks become hyper-relevant in the event that a party leader-an aspiring prime minister-genuinely desires policy change; especially major or complex policy change. In the event, the think tanks provide him or her and his or her party with critical tools (the necessary capacity) to meaningfully prepare for such change and, if the chutzpah be there, to lead and effect change when in government. Our modern democracy should demand no less. 